\title{
DOI 10.26886/2414-634X.3(39)2020.9
}

UDC 330.332 (477)

\section{CONCEPT OF MANAGEMENT OF INNOVATIVE PROCESSES OF} THE REGIONAL TOURIST AND RECREATIONAL COMPLEX

\section{O. G. Pidvalna, PhD of Economic Sciences, Associate Professor}

np070101@gmail.com

Vinnytsia National Agrarian University, Ukraine, Vinnytsia

The article clarifies the concept of "innovation" in the field of tourism business in the region. The theoretical and methodological basis of the study is the work of domestic and foreign scientists in the theory of innovation and innovation, problems of business development in tourism, regional economy and sustainable development. The classification of innovations depending on their use in various areas of tourist activity is developed. The components for building the concept of innovative strategy for the development of the tourist and recreational complex of the region are presented.

Key words: tourist-recreational complex, services, innovations, innovation, strategy, management, development.

Підвальна О. Г., кандидат економічних наук, доцент, Концепція управління інноваційними процесами регіонального туристичнорекреаційного комплексу / Вінницький національний аграрний університет, Україна, Вінниця

В статті уточнено поняття «інновації» стосовно сфрері туристичного бізнесу регіону. Теоретико-методологічною основою дослідження $є$ праці вітчизняних та зарубіжних вчених в теорії інновації та інноваційної діяльності, проблем розвитку підприємницької діяльності в сфрері туризму, регіональної економіки та проблеми стійкого розвитку. Розроблена класифрікація інновацій в 
залежності від використання їх в різних областях туристичної діяльності. Наведено компоненти для побудови концепції інноваційної стратегії розвитку туристично-рекреаційного комплексу регіону .

Ключові слова: туристично-рекреаційний комплекс, послуги, інновації, інноваційність, стратегія, управління, розвиток.

Постановка проблеми. Однією із загальносвітових тенденцій розвитку є підвищення ролі та значущості сфрери послуг в соціальноекономічній системі національного господарства. Це виражається в стійкому підвищенні частки цієї сфрери в ВВП провідних ринкових країн. Сумарна частка послуг у ВВП розвинених держав за даними на 2019 р. становить «70-80\% (США - 79,6\%, Франція - 77,6\%, Греція - 75,3\%, Великобританія - 74,5\%), в той час як в Україні даний показник знаходиться в межах 60\% (причому в 1990 році він становив лише $34,9 \%)$.

Дана тенденція повинна поєднуватися з іншим важливим трендом світового розвитку - активізацією інноваційних процесів. У зв'язку з цим актуальність дослідження інноваційних процесів в сфрері послуг, оосбливо в туристичній галузі регіону на даному часі $€$ доцільною.

Аналіз останніх публікацій та досліджень. Проблемам становлення та розвитку інноваційної діяльності присвячено праці таких науковців, як: А. Вдовічен, М. Вознюк, В. Геєць, О. Жихор, М. Канаєва, А. Князевич, О. Маслак, В. Іванова, М. Рахова, С. Ракицька, Т. Решетілова, Н. Рудь, О. Рочева, В. Савченко, С. Ткач, В. Ткаченко, В. Трибушна, 3. Пересунько, І. Федишин, Б. Холод, О. Чернега, І. Чудаєва, Г. Швець, Д. Шестакова, 3. Юринець та ін.

У той же час даний аспект інноваційної діяльності, що стосується саме сфрери послуг, недостатньо вивчений. В значній мірі це обумовлено тим, що поняття інновації (i інноваційної діяльності в тому 
числі) довгий час трактувалося дуже вузько - в основному в технологічній та технічній сфрері.

Постановка завдання. Мета статті полягає в уточнені поняття інновацій стосовно сфрері туристичного бізнесу та розробити класифікацію інновацій в залежності від використання їх в різних областях туристичної діяльності регіону.

Виклад основного матеріалу дослідження. Починаючи з 2005 року з'явилися офріційні документи, в яких зафіксована більш розширене трактування поняття інновацій. Зокрема, В новому Керівництві Осло (2005) в поняття інноваційного процесу були включені нововведення в області організації і маркетингу [5]. Це створює методичні передумови для дослідження інноваційних процесів в сфрері послуг, в якій частка даних видів діяльності традиційно дуже висока.

Поняття "інновація" означає комплексний процес створення, розповсюдження й використання нововведення, яке сприяє розвитку та підвищенню ефективності роботи підприємств, а також задоволенню певних потреб [1-4]. Термін “інновація" почав активно використовуватися в перехідній економіці України самостійно і для позначення ряду родинних понять: “інноваційна діяльність", “інноваційний процес”, “інноваційне рішення”. У світовій економічній літературі “інновація” інтерпретується як “...перетворення потенційного науково-технічного прогресу в реальний, що втілюється в нових продуктах і технологіях та характеризується більш високим технологічним рівнем, новими споживчими якостями товару у порівнянні з попереднім продуктом".

Поняття “інновація" застосовується до нововведень у виробничій, організаційній, фрінансовій, науководослідній, навчальній та інших сфрерах, до будь-яких удосконалень, що забезпечують економію витрат або створюють умови для такої економії. 
Основними видами інновацій в сфері послуг можуть бути:

1) нові або поліпшені послуги (розширення продуктової лінії);

2) нові або поліпшені виробничі процеси і технології надання послуг (процесні і технологічні інновації);

3) змінені соціальні відносини (соціальні або кадрові інновації);

4) нові або вдосконалені організаційно-економічні системи (організаційні інновації);

5) нові або вдосконалені методи управління, включаючи маркетинг та інноваційний менеджмент (управлінські інновації);

6) нові або модернізовані інформаційно-обчислювальні технології, що використовуються на підприємстві сфери послуг і т.д.

Одним із завдань дослідження $є$ конкретизація поняття інновації для найважливішої галузі сфрери послуг регіону, якою є туризм. У ряді країн він займає провідні позиції в їх економіці і служить головним джерелом поповнення їх бюджету. Таким чином, розвиток туризму $є$ важливим показником, що характеризує відкритість економіки країни, а також пріоритети державної політики, орієнтованої на облік сучасних тенденцій до глобалізації, інтеграції і міжкультурної взаємодії різних країн. Крім того, фрормування ефективно фрункціонуючого туристського комплексу $\epsilon$ в багатьох країнах «локомотивом» економічного зростання.

Можливості туризму для розвитку національної економіки виявилися не-реалізованими, оскільки хоча Україна і володіє багатим туристично- рекреаційним потенціалом, але він в даний час недостатньо затребуваний.

Специфіка туризму (на відміну від інших галузей даної сфрери народного господарства) складається в тісній прив'язці його до конкретної регіону. Так, якщо такі галузі сфрери послуг, як громадське харчування або побутове обслуговування населення практично 
індиферентні по відношенню до регіону їх дислокації, то з туризмом справа йде протилежним чином. Процес задоволення послуг в громадському харчуванні або побутовому обслуговуванні населення в цілому характеризується регіональною нейтральністю і відносно слабкою мінливістю при зіставленні цих галузей для різних регіонів.

Що стосується туризму, то регіони характеризуються дуже великою різноманітністю надання даного виду послуг. Окремі регіони мають унікальну архітектуру та історичні пам'ятки, інші - великі рекреаційні можливості. Відповідно, і спектр послуг, що надаються, і можливості реалізації інноваційних процесів в різних регіонах будуть різними.

Інновації означають перше використання нововведення в регіоні (або на підприємстві) незалежно від того, чи застосовувалося воно денебудь раніше. Інакше кажучи, з точки зору окремої компанії (регіону) навіть імітація може мати характер інновації, а з точки зору народного господарства - його же захід інновацією не $є$, якщо воно вже використовується на іншому підприємстві (в іншому регіоні).

Таким чином, при аналізі інноваційних видів туристичних послуг завжди слід здійснювати вибір потенційних інновацій виходячи 3 більшості можливостей конкретного регіону. Відповідно, інноваційні процеси в туристичній галузі в методичному відношенні повинні бути розглянуті у взаємозв'язку з регіональним аспектом.

Причому слід враховувати не тільки природно-рекреаційні ресурси, але і рівень економічного розвитку регіону, що $є$ базою для розвитку туристичної індустрії. Іншими словами, інноваційні процеси повинні бути органічно вписані як в туристично-рекреаційний комплекс (ТРК) регіону, так і в регіональну економіку в цілому.

ТРК - це складна багатокомпонентна система, що має чіткі адміністративно-територіальні одиниці, що характеризується певним 
набором природно-кліматичних ресурсів і володіє певною привабливістю для туристів. В ії склад входить високорозвинена індустрія гостинності, розгалужена транспортна мережа, набір різноманітних пам'яток, телекомунікаційна інфрраструктура, сприятливе середовище проживання, що забезпечує отримання лікувальнопрофрілактичних і рекреаційних процедур.

Поряд з великим числом наявних в науковій літературі визначень інновації, існує також безліч класифрікацій видів інновації за різними критеріями, таким як [5]:

1. Значимість (базисні, поліпшуючі, псевдоінновації);

2. Спрямованість (замінюють, раціоналізує, що розширюють);

3. Місце реалізації (галузь виникнення, галузь застосування, галузь споживання);

4. Глибина зміни (регенерування первинних способів, зміни кількості, перегрупування, адаптивні зміни, новий варіант, нове покоління, новий вид, новий рід);

5. Розробник (розроблені силами підприємства, зовнішніми силами);

6. Масштаб поширення (для створення нової галузі, застосування у всіх галузях);

7. Місце в процесі виробництва (основні продуктові і технологічні, що доповнюють продуктові і технологічні);

8. Характер задовольняючих потреб (нові потреби, існуючі потреби);

9. Ступінь новизни (на основі нового наукового відкриття, на основі нового способу застосування до давно відкритим явищ);

10. Час виходу на ринок (інновації-лідери, інновації-послідовники);

11. Причина виникнення (реактивні, стратегічні); 
12. Область застосування (технічні, технологічні, організаційноуправлінські, інформаційні, соціальні і т.д.).

$€$ також «кластерні» класифрікації (зазвичай - іменні), базуються на цілому наборі класифрікаційних ознак.

Далі наведемо класифрікацію інновацій стосовно туристичної галузі. Вона $є$ Відповідно до проведеного за участю автора дослідження, в найближчій перспективі слід очікувати попит на такі види інноваційних туристичних послуг як:

-Екологічний туризм (з вивченням заповідників і виявленням порушень в екології). Даний вид туризму крім виховання у населення бережного ставлення до природи може приносити також суспільну користь: збір інформації про стан природного середовища сприяє ефективній роботі органів екологічного нагляду.

- Етнографрічний туризм (з вивченням побуту і традицій народу). В даний час подібний вид туристичних послуг вже $є$ в багатьох країнах і користується популярністю. Однак для багатьох регіонів держави він $є$ чимось особливим. До цього виду туризму примикає і археологічний туризм.

- СПЛ-туризм (з організацією СПА-процедур на базі мінеральних джерел і цілющих грязей). СПЛ-туризм в даний час широко розповсюджений в розвинених європейських країнах (Франція, Швейцарія, Німеччина), а також на кращих курортах Тунісу, Туреччини та інших країн. Організація даного виду туризму в окремих регіонах вивела б його на світовий рівень.

- Агротуризм або сільськогосподарський туризм (заняття землеробством і скотарством на спеціально виділених ділянках). В даний час жителі мегаполісів відчувають значний стрес, пов'язаний із зайвою урбанізацією середовища їх проживання: скупченість населення, загазованість, автомобільні пробки і т.д. Робота на землі не 
тільки знімає стрес і приносить оздоровчий ефект, але корисна ще й своїм результатом - отриманням екологічно чистого сільськогосподарського продукту.

Впровадження нових видів туристичних продуктів зумовить залучення в туристичний бізнес нові верстви населення. Так, агротуризм може виявитися привабливим своєю доступністю для населення 3 низьким рівнем доходів; етнотуризм - для колишніх співвітчизників, які проживають за кордоном і бажають відвідати місця проживання своїх предків. Екотуризм - для екологів і представників партії «зелених».

Ще один напрямок вдосконалення туризму полягає в інтеграції інформаційного простору в даній сфері послуг. В даний час туристична індустрія в багатьох регіонах представлена великою кількістю малих турфірм. Курс на переважне розвиток регіонального малого бізнесу $є$, як правило, стратегічно вірним рішенням. Малий бізнес сприяє забезпеченню зайнятості в регіоні, що характеризується значною часткою безробітного населення, сприяє зростанню добробуту громадян.

3 метою координації діяльності малих фрірм у великому регіоні доцільно створення єдиного центру, що виконує інформаційні, координаційні і диспетчерські функції. Робота такого центру поліпшила б такі аспекти туристичного бізнесу як замовлення і продаж путівок, отримання довідкової інформації, моніторинг діяльності фрірм і ін. До числа важливих інновацій в туристичному бізнесі $\epsilon$ впровадження ресурсозберігаючих і природоохоронних технологій. Туризм як галузь має виражену орієнтацію на використання природних ресурсів. На відміну від інших галузей він сам викликає потужні міграції людей до місць зосередження рекреаційних ресурсів. Крім того, повинні бути 
передбачені заходи щодо ліквідації виникає збитку на основі відновних технологій.

Концепція інноваційної стратегії розвитку туристичнорекреаційного комплексу регіону будується з наступних інноваційних компонентів:

1) продуктивна інновація: екологічний туризм; етнографрічний туризм; СПА; агротуризм.

2) інфрормаційна інновація: централізована довідникова служба; бронювання та продаж путівок; моніторинг оперативної діяльності турфрірми.

3) управлінська інновація: аналітична оцінка економічної ефективності; планування та прогнозування діяльності комплексу.

4) екологічна інновація - ресурсозберігаючі технології.

Висновки. Впровадження даного асортименту інноваційних послуг неможливо, по-перше, без їх економічного обґрунтування (на основі економіко-математичних моделей і методів); а по-друге, без розробки відповідних організаційно-економічних механізмів, що забезпечують потрапляння на ринок туристичних послуг i подальше їх функціонування. 3 цією метою мають бути здійснені інновації в галузі знань - створення нових економіко-математичних методів оцінки ефективності використовуваних технологій при наданні туристичних послуг, обґрунтування різних стратегій управління туристичними підприємствами, оптимізації асортименту і структури розглянутих послуг, а також інші методи і моделі, орієнтовані на вдосконалення менеджменту в туристичній діяльності регіону.

\section{תimepamypa:}

1. Жихор О.Б. (2009) Роль теорій інновацій та інноваційного розвитку у формуванні регіональної інноваційної політики. Економіка промисловості. № 1. С. 132-137. [in Ukrainian] 
2. Іванова В.В. (2009) Дослідження теорії поняття інновації. Журнал «Економіка Промисловості». №47. С. 111-120. [in Ukrainian]

3. Пересунько 3. М. (2013) Теоретичні аспекти розвитку інноваційної теорії. Електронне наукове фрахове видання «Ефрективна економіка». №7. http://www.economy.nayka.com.ua/?op=1\&z=2192. [in Ukrainian] (2020, Травень, 1)

4. Федишин І.Б. (2012) Етимологічне походження та теоретичні засади категорії «інновація» та ії̈ класифрікаційні ознаки. Вісник Вінницького політехнічного інституту. №3. C. 42-47. [in Ukrainian]

5. Clark G. (2018) The Innovation Economy Implications and Imperatives for States and Regions. NSW Innovation and Productivity Council https://www.industry.nsw.gov.au/_data/ assets/pdf_file/0007/163267/IPCThelnnovation-Economy-2018.pdf. [in English]. (2020, Березень, 21)

\section{References:}

1. Zhykhor, O.B. (2009), Rol' teorij innovacij ta innovacijnogo rozvytku u formuvanni regional'noi' innovacijnoi' polityky [The role of innovation theory and innovation in the formation of regional innovation policy] Industrial economics, vol. 1, P. 132-137.

2. Ivanova, V.V. (2009), Doslidzhennja teorii' ponjattja innovacii' [The study of the theory of the concept of innovation], Industrial economics, vol. 47, no. 4

3. Peresunko, Z.M. (2013), Teoretychni aspekty rozvytku innovacijnoi' teorii' [Theoretical aspects of innovation theory], Electronic scientific professional publication "Effective Economics", vol. 7, Available at: http://www.economy.nayka.com.ua/?op=1\&z=2192, (2020, May, 1)

4. Fedyshyn, I.B. (2012), Etymologichne pohodzhennja ta teoretychni zasady kategorii' «innovacija» ta i'i' klasyfikacijni oznaky [The etymological origin and theoretical basis of the category "innovation" and its classification features], Bulletin of Vinnytsia Polytechnic Institute, vol. 3, pp. 42-47. 
5. Clark G. (2018) The Innovation Economy Implications and Imperatives for States and Regions NSW Innovation and Productivity Council, Available at:

https://www.industry.nsw.gov.au/_data/assets/pdf_file/0007/163267/IPCThelnnovation-Economy-2018.pdf. (2020, March, 21)

Citation: O. Pidvalna (2020). CONCEPT OF MANAGEMENT OF INNOVATIVE PROCESSES OF THE REGIONAL TOURIST AND RECREATIONAL COMPLEX. 3(39). doi: 10.26886/2414-634X.3(39)2020.9

Copyright: O. Pidvalna (C. 2020. This is an openaccess article distributed under the terms of the Creative Commons Attribution License (CC BY). The use, distribution or reproduction in other forums is permitted, provided the original author(s) or licensor are credited and that the original publication in this journal is cited, in accordance with accepted academic practice. No use, distribution or reproduction is permitted which does not comply with these terms. 